\title{
Pemanfaatan Penggunaan E-Commerce Pada Usaha Pembibitan Srikaya Jumbo Dan Jambu Madu Deli Di Desa Punten Kecamatan Bumiaji Kota Batu
}

\author{
Dyanasari $^{1}$, Eri Yusnita Arvianti ${ }^{2}$, Poppy Indrihastuti ${ }^{3}$ \\ ${ }^{1,2}$ Agribisnis - Fakultas Pertanian, ${ }^{3}$ Manajemen - Fakultas Ekonomi \\ 1,2,3 Universitas Tribhuwana Tunggadewi \\ e-mail:yusnitaarvianti@yahoo.co.id
}

\begin{abstract}
Abstrak
Permintaan akan bibit tanaman buah unggul meningkat dari waktu ke waktu Kebutuhan akan pentingnya pemilihan teknik pemasaran yang tepat akan mempengaruhi jumlah penjualan dari usaha tersebut. Media pemasaran yang tepat terutama media pemasaran yang modern sangat diperlukan oleh para mitra di Desa Punten Kota Batu. Melalui program PKM ini diharapkan memberikan terobosan baru di bidang pemanfaatan teknik pemasaran modern E-commerces sehingga usaha pembibitan srikaya jumbo dan jambu madu deli dapat lebih cepat dikenal oleh masyarakat melalui peningkatan kuantitas permintaan terhadap bibit tanaman tersebut, yang pada akhirnya akan mendatangkan tingkat keuntungan yang lebih besar. Metode yang diterapkan pada kedua kelompok ini adalah metode pemberdayaan masyarakat, melalui kegiatan pelatihan, penyuluhan, dan pendampingan dengan pengenalan teknologi pembuatan pupuk dan E-commerces. Hasilnya dengan E-commerce usaha tersebut bisa dikenal dengan berbagai item pelayanan yang ada mulai dari jenis produk, harga, kegunaan, cara perawatan, dan cara pengiriman. Sehingga jumlah penjualan srikaya jumbo dan jambu madu deli dapat lebih cepat dan bisa lebih terkuantitatifkan.
\end{abstract}

Kata kunci : E-commerce; jambu madu; srikaya jumbo

\begin{abstract}
The need for choosing the right marketing techniques will affect the amount of sales from the business. Appropriate marketing media, especially modern marketing media is needed by the Partners in the Village Punten Kota Batu. Through this PKM program is expected to provide a new breakthrough in the field of utilization of modern marketing techniques E-commerces so that the business of sumbaya jumbo jambo and jambu deli can be more quickly recognized by the community through increasing the quantity of demand for the seeds of the plant, which in turn will bring more profit levels big. The methods applied to both groups are community empowerment methods, through training, counseling and mentoring activities with the introduction of fertilizer technology and E-commerces. The result with E-commerce business can be known by various items of service that exist from the type of product, price, usability, how to care, and how to send. So the number of sales can be more quantitative.
\end{abstract}

Keywords : e-commerce; srikaya large; guava honey 


\section{PENDAHULUAN}

Posisi Indonesia pada kawasan tropis memang memberi nilai tambah tersendiri. Salah satunya dengan membanjirnya beragam buah yang menjadikannya sebagai aset yang sangat menjanjikan dalam dunia agribisnis. Buah tropis yang terkenal dengan warna yang cantik, rasa yang segar menjadikan permintaan untuk buah-buahan tropis ini cukup tinggi baik di pasaran lokal maupun di pasar internasional. Hal ini menuntut kualitas buah yang terbaik serta tentu saja dalam kuantitas yang tidak sedikit ${ }^{1}$.

Semakin banyaknya berbagai penemuan bibit tanaman buah unggul, mendorong para pelaku usaha mulai melirik usaha bidang agribisnis ini. Permintaan akan bibit tanaman buah unggul meningkat dari waktu ke waktu. Bibit tanaman buah unggul menjadi sebuah pasar tersendiri dengan permintaan yang tinggi, namun sedikit penawaran. Tidak banyak pelaku pasar yang tertarik untuk menjadi penjual bibit. Sekilas memang usaha pembibitan ini terkesan lebih rumit dan beresiko. Padahal dengan sedikit ketelatenan dan kesabaran usaha pembibitan ini akan dapat mendatangkan keuntungan yang besar dan menggiurkan ${ }^{2}$.

\section{SUMBER INSPIRASI}

Permasalahan yang sering terjadi pada usaha pembibitan srikaya jumbo dan jambu madu deli adalah rendahnya tingakat pengetahuan tentang teknologi dan media pemasaran yang tepat. Desa Punten adalah salah satu desa yang terkenal dengan jeruk batu 55 . Permintaan jeruk batu 55 terlihat meningkat setiap tahunnya. Namun karena kondisi semakin banyaknya pengusaha jeruk batu 55 menimbulkan persaingan yang ketat dalam usaha bisnis tanaman tersebut. Keadaan tersebut dimanfaatkan oleh sekelompok pemuda di Desa Punten untuk mencoba melirik usaha pembibitan lain melalui usaha pembibitan srikaya jumbo dan jambu madu deli. Selain jenis buahnya langka harga buahnyapun sangat tinggi dan jarang ditemukan adanya persaingan ketat pada usaha pembibitan dan penjualan buah dari usaha tersebut. Kedua tanaman tersebut menjadikan primadona baru apabila mampu dirintis dan diusahakan secara baik. Melihat kondisi tersebut, dimanfaatkan oleh sebagian pemuda desa yang tergabung dalam karang taruna Kelompok Putra Mahkota dan Kelompok Merak Bersemi.

Potensi buah unggulan ini memiliki peluang yang tinggi apabila diusahakan secara baik. Namun potensi ini memiliki kendala yaitu masih rendahnya teknologi pembuatan pupuk kompos dan POC serta sistem pemasaran yang masih tradisional.Kebutuhan pentingnya pemilihan teknologi pembuatan pupuk kompos dan POC serta media pemasaran yang tepat sangat diperlukan para mitra di desa Punten ${ }^{3}$. Salah satunya adalah dengan media E-commerce. Melalui program PKM ini dapat memberikan terobosan baru di bidang teknik pemasaran modern sehingga usaha pembibitan srikaya jumbo dan jambu madu deli dapat lebih cepat dikenal oleh masyarakat dan mendatangkan tingkat keuntungan yang besar. Dalam program PKM ini akan diperkenalkan teknik dan media pemasaran E-commerce yang nantinya akan diaplikasikan untuk meningkatkan omset penjualan bibit tanaman. Salah satu dampak positif dari teknologi ini adalah proses penyampaian informasi secara cepat karena dapat diakses melalui sebuah jaringan internet maupun situs-situs terkait. Proses transaksinyapun dapat berlangsung secara cepat dan lebih efisien.

\section{METODE KEGIATAN}

Lokasi penelitian terletak di Desa Puten, Kecamatan Bumiaji, Kota Batu yang dilaksanakan mulai bulain Mei sampai dengan November 2018. Penelitian ini bermitra dengan Kelompok putra Mahkota (Mitra 1) dan kelompok Merak Bersemi (Mitra 2). 
Pemanfaatan Penggunaan E-Commerce Pada Usaha Pembibitan Srikaya Jumbo Dan Jambu Madu Deli

Adapun langkah-langkahnya adalah:

a. Perkenalan seluruh Tim PKM dengan mitra II, mendengarkan permasalahan yang dikeluhkan oleh mitra II dan memberikan pendekatan serta solusi yang bisa ditawarkan melalui kesepakatan bersama.

b. Tim PKM memberikan pelatihan pemsaran online melalui website atau (E-commerce).

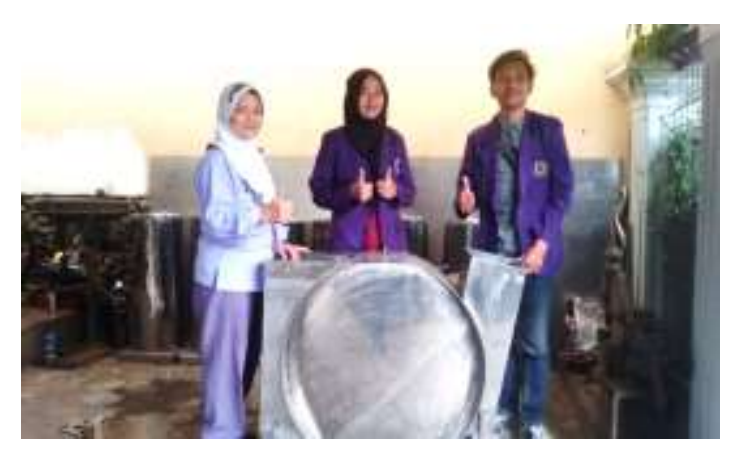

Gambar 1. Mesin pupuk kompos \& POC

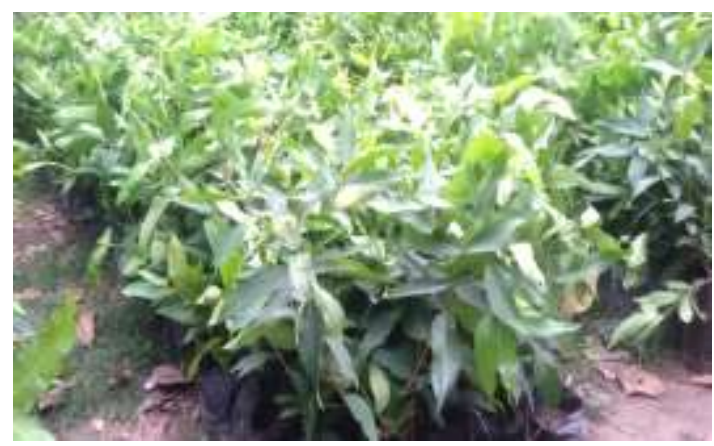

Gambar 3. Bibit Jambu Madu Deli

\section{ULASAN KARYA}

\section{Kelebihan dan Kelemahan Penggunaan E-commerce}

Kelebihan Ecommerce adalah untuk terus meningkatkan daya saing UKM serta untuk mendapatkan peluang ekspor dan peluang bisnis lainnya. Dengan menggunakan E-commerce, produsen dapat merubah daftar harga atau memberikan informasi kepada calon pembeli secara cepat melalui website. E-commerce juga bermanfaat dalam membangun database pelanggan yang komprehensif dan jumlah penjualan bisa lebih terkuantitatifkan ${ }^{4}$. Produsen dapat mempunyai c. Tim PKM memberikan pelatihan tentang sistem pemasaran secara online melalui media E-commerce meliputi : usaha penyebaran, pembelian, penjualan, pemasaran, pembibitan tanaman melalui media internet.

\section{KARYA UTAMA}

Beberapa bantuan yang diberikan adalah bantuan mesin pembuatan pupuk kompos dan pupuk POC, bibit jambu, bibit srikaya dan pembuatan media E-commerce.
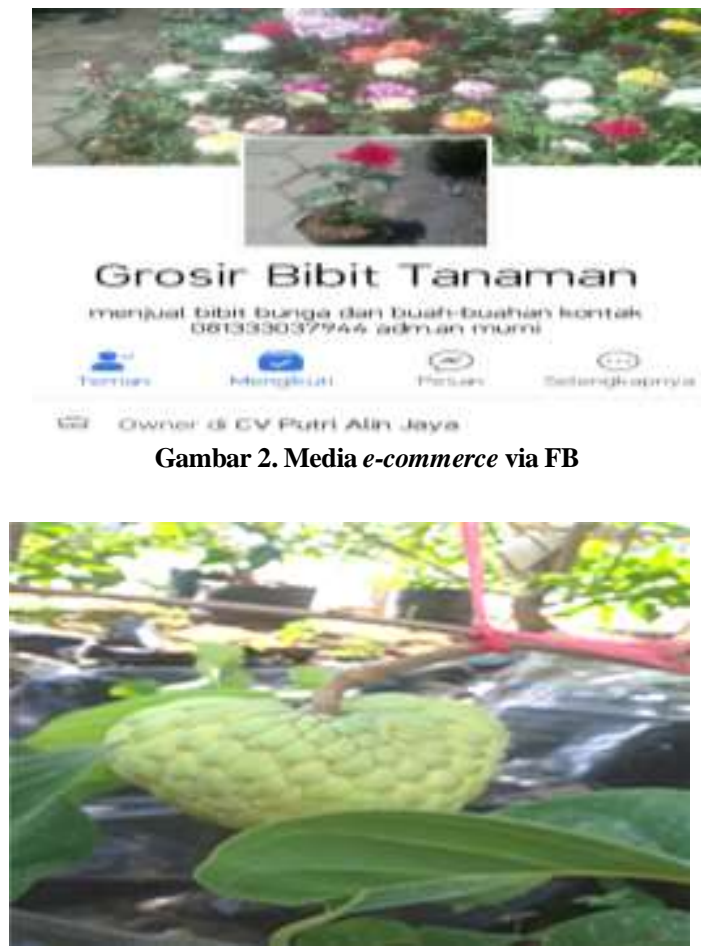

Gambar 4. Bibit Srikaya Jumbo

informasi tentang pola pemesanan yang dilakukan pelanggan dan mengelolanya sebagai informasi yang berharga yang dapat membantu dalam pemasaran dan strategi promosi. E- commerce juga membantu dalam menfasilitasi kegiatan pembelian yang nyaman. E-commerce dapat menghemat waktu pelanggan dibandingkan jika pelanggan tersebut melakukan pembelian secara offline $e^{5}$. Kelebihan penggunaan E-commerce yaitu dapat memperluas jaringan pasar, memperpendek jarak dengan konsumen (tanpa batas jarak dan waktu), efisiensi biaya operasional, konsumen dapat memperoleh informasi yang dibutuhkan dan bertransaksi degan cepat dan mudah. 
Sedangkan, kekurangan dari Ecommerce yaitu meningkatkan individualisme karena bertransaksi menggunakan media elektronik tanpa bertemu langsung antara penjual dan pembeli, terkadang menimbulkan kekecewaan karena barang yang ditampilkan di layar monitor berbeda dengan barang aslinya, tidak manusiawi karena tidak dapat berinteraksi secara langsung ${ }^{6}$. Melakukan kegiatan transaksi secara online berarti pelanggan akan terpaksa menyediakan sejumlah informasi pribadi yang dipersyaratkan oleh penjual. Persyaratan ini tentunya dapat mengganggu kerahasiaan dan menimbulkan isu tentang keamanan dari informasi yang disediakan. Isu nonteknis juga menjadi kendala dalam penggunaan E-commerce yaitu masih banyak pembeli yang tidak percaya dan susah merubah kebiasaannya untuk bertransaksi tanpa bertemu langsung dengan penjualnya.

\section{KESIMPULAN}

Melalui program PKM ini diharapkan memberikan terobosan baru di bidang teknik pemasaran modern E-commerce sehingga usaha pembibitan srikaya jumbo dan jambu madu deli dapat lebih cepat dikenal oleh masyarakat melalui peningkatan kuantitas permintaan terhadap bibit tanaman tersebut, yang pada akhirnya akanmendatangkan tingkat keuntungan yang lebih besar. Media E-commerce usaha tersebut bisa dikenal dengan berbagai item pelayanan yang ada mulai dari jenis produk, harga, kegunaan, cara perawatan, dan cara pengiriman. Sehingga jumlah penjualan bisa lebih terkuantitatifkan.

\section{DAMPAK DAN MANFAAT KEGIATAN}

Dengan adanya kegiatan ini kondisi ekonomi kedua mitra lebih sejahtera, tingkat produktivitas tanaman meningkat, Metode E-commerce sangat membantu dalam penjualan bibit tanaman, Kekompakan petani muda semakin meningkat, Pembuatan pupuk dengan menggunakan mesin, Kuantitas penjualan bisa dilihat / dikuantitatifkan, Peningkatan pada keuntungan dan mulai adanya pembukuan usaha.

\section{DAFTAR PUSTAKA}

1. Fuad, Christine, H., Nurlela., Sugiarto, Paulus, Y.E.F. "Pengantar Bisnis". Gramedia Pustaka Utama. Jakarta, 2013.

2. Wibowo, Singgih. "Pedoman Pengelolaan Perusahaan Kecil". Penebar Swadaya. Jakarta, 2013.

3. Suyanto, M."Strategi Periklanan pada Ecommerce Perusahaan Top Dunia”.Yogyakarta: Andi Offset, 2010

4. Jauhari, J. Upaya Pengembangan Usaha Kecil Menengah (UKM) Dengan Memanfaatkan ECommerce. Jurnal Sistem Informasi, 2(1), (2010); 159-168. https://doi.org/2355-461

5. Irmawati, D. "Pemanfaatan E-Commerce Dalam Dunia Bisnis". Jurnal Ilmiah Orasi Bisnis ISSN: 2085-1375 Edisi Ke-VI, November 2011, (November), (2011): 95-112

6. Nuryanti, "Peran E-Commerce Untuk Meningkatkan Daya Saing Usaha Kecil dan Menengah (UKM )". Jurnal Ekonomi Manajemen Ekonomi Universitas Riau, 21(4) (2013):15. https://doi.org/10.1073/pnas.0703993104 